\title{
Wzornictwo secesyjne $w$ aptekarstwie na przełomie XIX i XX wieku na przykładzie zbiorów Muzeum Farmacji Uniwersytetu Jagiellońskiego
}

\section{ABSTRACT}

Art Nouveau design in pharmacy in the late nineteenth and early twentieth century illustrated by the example of the Museum of Pharmacy of the Jagiellonian University

At the end of the nineteenth century, there appeared a new trend called Art Nouveau, which dominated all areas of fine arts, and was most fully expressed in architecture and crafts. The sites that were under the influence of Art Nouveau ornamentation, for understandable reasons, included also pharmacies. Pharmacy windows, emblems, furniture, pharmaceutical utensils, packaging for medicines, advertising and advertising catalogues were performed in accordance to this trend. Today, many of them can be seen in the Museum of Pharmacy of the Jagiellonian University.

Keywords: Art Nouveau, history of pharmacy, craftwork

Słowa kluczowe: secesja, historia farmacji, rzemiosło artystyczne

Wygląd aptek zmieniał się w ciągu wieków zależnie od mody, gustów i ich ówczesnej użyteczności. O urządzaniu aptek decydowali sami aptekarze. Oni to, w zależności od posiadanej wiedzy fachowej, od smaku estetycznego oraz możliwości finansowych, zamawiali urządzenia apteczne u rzemieślników według własnych wymagań i upodobań. Dopiero w drugiej połowie XIX wieku zaczęły powstawać specjalistyczne przedsiębiorstwa, urządzające apteki według jednolitych, schematów ${ }^{1}$. Z ofertą tych firm można się

\footnotetext{
${ }^{1}$ W. Roeske, Polskie apteki, Wrocław-Warszawa-Kraków 1971, s. 104-105.
} 
było zapoznać dzięki reklamowym katalogom. Pomimo że przedmioty te wykonywano seryjnie, niezwykle dbano o ich estetykę i różnorodność formy.

Zwiedzając krakowskie Muzeum Farmacji, możemy dowiedzieć się, jak w dawnych wiekach wyglądały apteki. W stałej ekspozycji zobaczyć można meble apteczne w stylu renesansowym, barokowym, empire, biedermeier i eklektycznym ${ }^{2}$. Również wzornictwo naczyń i sprzętu aptecznego wpisywało się w swej estetyce w nurty stylów obowiązujących w danym okresie historycznym. Gdy pod koniec XIX wieku pojawił się w sztuce nowy nurt, zwany secesją, również apteki znalazły się pod wpływem jego wzornictwa. Witryny apteczne, godła aptek, meble, naczynia apteczne i opakowania na leki, wykonywano zgodnie z kanonem właściwym dla tego stylu.

Charakterystyczną cechę secesji stanowiła integracja sztuk, która polegała na zespoleniu wszelkich rodzajów twórczości, począwszy od architektury, poprzez malarstwo i rzeźbę, po sztukę użytkową i zdobnictwo. Secesja opanowała wszystkie dziedziny sztuk plastycznych, a najpełniej wypowiedziała się w architekturze i rzemiośle, które szczególnie nobilitowała. Według secesyjnej estetyki wystrój zewnętrzny budynku powinien tworzyć kompozycyjną i kolorystyczną jedność stylową z wystrojem wnętrza, meblami, zastawą stołową, a nawet strojem. Każdy mebel i sprzęt istniał jako część harmonijnej całości. W secesji każdy przedmiot codziennego użytku nabierał znaczenia dzieła sztuki. W praktyce dzieło architektury lub sztuki użytkowej zaczęło być traktowane przez artystów jako wartość sama w sobie. Projektowany przedmiot miał spełniać funkcję praktyczną, a jego piękny układ kształtów i kolorów wywołać określony nastrój³ Doskonale tę tendencję widać na przykładzie aptek, które na przełomie XIX i XX wieku często otrzymywały secesyjny wystrój. W zbiorach krakowskiego Muzeum Farmacji znajdują się katalogi wiedeńskich firm Hermann Steinbuch dawniej F.A. Wolf \& Söhne oraz Fabriken Pharmaceutischer Bedarfsartikel Hammer \& Voršak, które zajmowały się produkcją wyposażenia dla aptek. Już sama szata graficzna katalogów świadczy o tym, jak popularne w tamtym okresie było wzornictwo secesyjne. Na okładce pochodzącego z roku 1901 katalogu firmy Hammer \& Voršak widnieje piękny wizerunek Hygiei ozdobiony typową dla okresu secesji ornamentykąa (il. I).

Wspomniane firmy oferowały bogaty asortyment wszelkich, niezbędnych do pracy w aptece utensyliów recepturowych, naczyń aptecznych, a także propozycje gotowych zestawów mebli aptecznych. Fotografie zamieszczone w katalogach przedstawiają przykładowe, istniejące już apteki. Większość z nich ma wystrój secesyjny. Zauważamy charakterystyczną dla tego okresu dbałość o jednolitość wystroju. Do secesyjnych mebli aptecznych pasują elementy wystroju wnętrz, np. lampy, fotele dla pacjentów czy nawet stojaki na parasole. O pietyzmie, z jakim urządzone były prezentowane wnętrza, świadczy fakt, że ściany pomieszczeń, w których znajdują się apteki, pomalowane zostały W secesyjne ornamenty ${ }^{5}$ (il. 1, 2).

${ }^{2}$ Z. Bela, Style mebli aptecznych w stałej ekspozycji krakowskiego Muzeum Farmacji [w:] Rozwój aptekarstwa śląskiego. Moda i styl w aptekach polskich ze szczególnym uwzględnieniem Śląska i jego specyfiki, red. A. Marek, B. Urbanek, Katowice 2014, s. 261-280.

3 B. Kowalska, Od impresjonizmu do konceptualizmu. Odkrycia sztuki, Warszawa 1989, s. 30.

${ }^{4}$ Katalog Fabriken Pharmaceutischer Bedarfsartikel Hammer \& Voršak, Wien 1901.

${ }^{5}$ Katalog firmy Hermann Steinbuch vormals F.A. Wolf \& Söhne, Wien 1911, s. 9-19. 


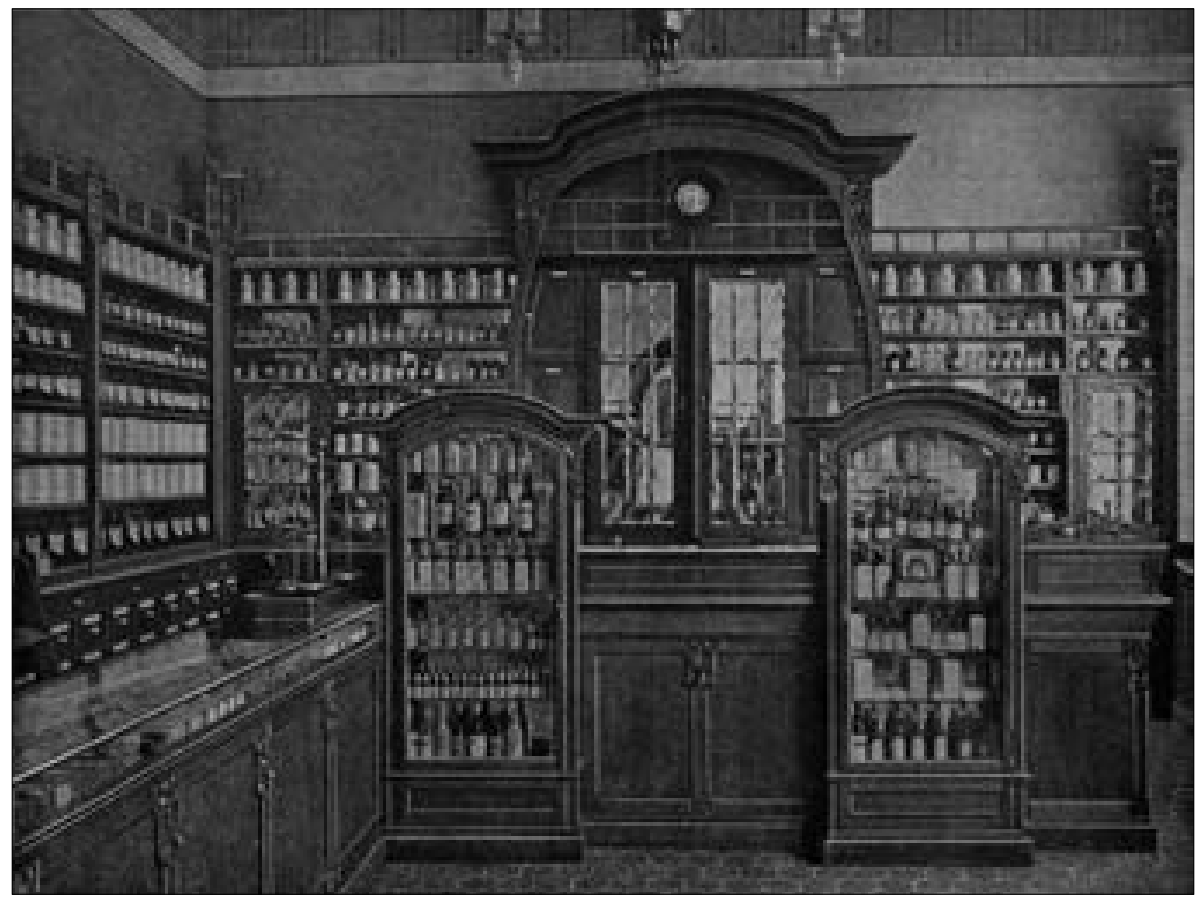

Il. 1. Jedna z propozycji secesyjnego wyposażenia apteki pochodzącą z katalogu firmy Hermann Steinbuch (1911) (ze zbiorów Muzeum Farmacji w Krakowie). Fot. M. Urbanik

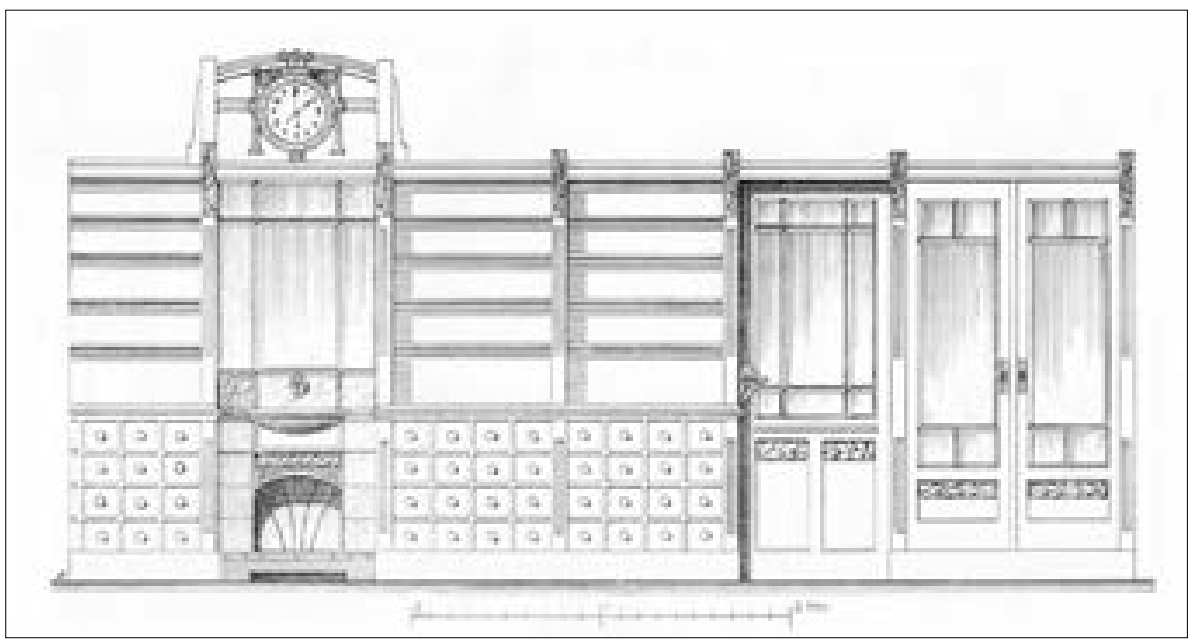

Il. 2. Projekt mebli aptecznych z katalogu firmy Hermann Steinbuch (1911) (ze zbiorów Muzeum Farmacji w Krakowie). Fot. M. Urbanik 
Katalogi oferowały także naczynia apteczne wykonane z ceramiki i ze szkła przeźroczystego, kolorowego oraz mlecznego. Zwraca uwagę niezwykła różnorodność etykiet umieszczonych na tych naczyniach, w większości utrzymanych w stylu secesji (il. II). Obok wzornictwa z bujną dekoracją funkcjonował również nurt bardziej surowy, linie krzywe zastępowano prostymi, a formy faliste - geometrycznymi. Ten surowy styl charakteryzował się niemal zupełnym brakiem motywów roślinnych, a charakterystyczne dla wcześniejszego okresu ornamenty ograniczono do minimum (il. III). Naczynia apteczne o takiej stylistyce, charakterystycznej dla późnej odmiany niemiecko-austriackiej secesji, prostoliniowej z kultem kwadratu i koła ${ }^{6}$, pochodzące z wytwórni Hermann Steinbuch, dawniej F.A. Wolf \& Söhne, znajdowały się w aptece „Pod Orłem”. Aptekę (w Podgórzu przy placu Zgody) założył Józef Pankiewicz (1865-1942) w 1909 roku. W latach trzydziestych XX wieku została przejęta przez jego syna, Tadeusza Pankiewicza (1908-1993). W marcu 1941 roku w tej części Podgórza, gdzie ulokowana była apteka, Niemcy utworzyli getto. Dzięki staraniom właściciela apteka nie została zlikwidowana i funkcjonowała przez cały okres istnienia getta. Tadeusz Pankiewicz oraz jego współpracownicy aktywnie pomagali i wspierali mieszkańców getta. Apteka była miejscem spotkań, wymiany informacji, punktem przekazywania nielegalnej korespondencji i pieniędzy. W aptecznym schowku ukrywano drogocenne „Tory” i pamiątki rodzinne? Za działalność w czasie wojny Tadeusz Pankiewicz został w 1983 roku odznaczony medalem „Sprawiedliwy Wśród Narodów Świata”. Kilka lat po wojnie apteka „Pod Orłem" została zlikwidowana. Od 1983 roku w dawnej siedzibie tej apteki, przy placu Bohaterów Getta, istnieje Muzeum Pamięci Narodowej, które jest jednym z oddziałów Muzeum Historycznego Miasta Krakowa. Z okazji obchodów siedemdziesiątej rocznicy likwidacji krakowskiego getta ten oddział muzeum otrzymał nowy wystrój. Odtworzone na podstawie zachowanych fotografii wnętrze oglądać dziś można na wystawie „Apteka Tadeusza Pankiewicza w getcie krakowskim”, opowiadającej historię aptekarza, apteki i krakowskiego getta. Autorzy ekspozycji starali się oddać klimat i atmosferę apteki z okresu okupacji hitlerowskiej. Na półki odtworzonych mebli aptecznych powróciły secesyjne naczynia, niestety, nie te oryginalne, lecz zrekonstruowane na podstawie firmowych katalogów i zachowanych fotografii.

W początkach XX wieku, w okresie kiedy secesja była w modzie, powstało w Krakowie kilka aptek. Większość z nich w ostatnich latach została zlikwidowana, a te, które pozostały, zmieniły swój wystrój. Jedynie apteka „Pod Opatrznością”, znajdująca się przy ul. Karmelickiej 23, do dzisiaj zachowała swój secesyjny wystrój. Apteka powstała w roku 1907 i należała do krakowskiej aptekarskiej rodziny Rederów. Jej założycielem i pierwszym właścicielem był Maksymilian Reder, a po jego śmierci w 1930 roku, aptekę przejął syn Zenon. Ostatnim, przed upaństwowieniem w roku 1951, właścicielem apteki był Alfred Reder. Apteka działa do dzisiaj i jest jedną z ostatnich historycznych aptek Krakowa. Jej ozdobą są pieczołowicie odnowione zabytkowe, secesyjne meble i secesyjna posadzka. Apteka „Pod Opatrznością” była znana w Krakowie m.in. z takich preparatów, jak „Mgra Redera płyn na odciski”, „Pasta Redera do zębów”, krem do opalania o nazwie „Plażol” i krem „Gładzik”. Etykiety i opakowania na te leki można dzisiaj oglądać na wystawie urządzonej pod hasłem „Co zostało z dawnych krakowskich

${ }^{6}$ S.T. Madsen, Art Nouveau, Warszawa 1987, s. 40.

7 T. Pankiewicz, Apteka w getcie krakowskim, Kraków 1947. 
aptek”, będącej częścią stałej ekspozycji w Muzeum Farmacji (il. IV). Na wystawie zgromadzono wiele pamiątek związanych z dawnymi krakowskimi aptekami. Jest wśród nich wiele etykiet, reklam, druków, na których wyraźnie widać secesyjne zdobnictwo, m.in. etykietki i torebki na leki z mieszczącej się jeszcze do niedawna przy ul. Grodzkiej apteki „Pod Złotym Słoniem”, druki firmowe i opakowania z apteki „Pod Gwiazdą”, która mieściła się przy ul. Floriańskiej 15, oraz opakowania z apteki „Pod Złotą Głową”, mieszczącej się w Rynku Głównym 13.

Na szczególną uwagę zasługuje kolekcja etykiet, opakowań i reklam pochodzących z krakowskiej apteki „Pod Złotym Tygrysem”, mieszczącej się przy ul. Szczepańskiej 1, z początku XX wieku9 (il. V). Od 1903 roku, kiedy właścicielem apteki zostali Karol Jahr i Henryk Blumenfeld, w jej laboratorium produkowano wiele znanych w kraju i za granicą specyfików. Marką ochronną produkowanych leków była głowa tygrysa okolona wężem. Większość z tych pięknych, kolorowych etykiet utrzymana jest w charakterystycznym dla początku XX wieku secesyjnym stylu. Apteka „Pod Złotym Tygrysem” słynęła m.in. z linii kosmetyków znanych pod nazwą Balnodor Jahra. Były to kremy, mydła, pudry i tabletki aromatyczne do kąpieli, które - jak można wyczytać na ulotkach - „stanowią prawdziwą zdobycz w dziale przetworów służących do upiększania i wydelikacenia cery i skóry". Wśród nich były: Jahra Balnodor Krem - reklamowany jako „niezrównany środek kosmetyczny do pielęgnowania cery i skóry”, Jahra Balnodor Mydło, które „odznaczało się właściwą olejkowatością, było zupełnie obojętne i posiadało wykwintną i delikatną woń”, Jahra Balnodor Puder, składający się z „,najczystszych substancji, bez śladu dodatków metalicznych", Jahra Balnodor Tabletki do mycia i do kąpieli, które „dodane do wody nadają tejże nader przyjemną i trwałą woń, a wskutek swych składników wydzielają stosowna ilość kwasu węglowego, przez co odświeżają skórę”" Ważnym produktem apteki „Pod Złotym Tygrysem” był Petrogen Jahra, reklamowany jako „niezrównany środek do konserwowania włosów”. Według producenta, ,używany codziennie, odświeżał i wzmacniał cebulki włosowe, usuwał łupież i świąd z głowy, nadawał włosom połysk i miękkość i zapobiegał wypadaniu”. Dodatkowym atutem produktu było zapadające w pamięci opakowanie $\mathrm{z}$ wizerunkiem powabnej kobiety.

Sztukę secesyjną charakteryzowała dekoracyjna stylizacja. Jednym z głównych środków wyrazu była falista, długa, dynamiczna linia o niespokojnych i płynnych rytmach. Charakterystycznymi motywami nowej ikonografii były irysy, lilie i powoje, ważki, motyle, a nade wszystko kobiety, esowato wygięte, o nieprawdopodobnie długich, rozwianych, opadających faliście włosach. Często w secesyjnej stylizacji przedstawiana była bogini zdrowia - Higieja ${ }^{11}$. W oknie jednej z muzealnych sal zobaczyć możemy utrzymane w stylu secesji witraże, datowane mniej więcej na rok 1900, przedstawiające Higieję i Aklepiosa. Wizerunek Higiei jako element zdobniczy możemy dostrzec

${ }^{8}$ W 2009 roku apteka „Pod Złotym Słoniem” została zlikwidowana, obecnie zabytkowe meble $\mathrm{z}$ apteki znajdują się w holu Muzeum Farmacji.

9 Katalog opakowań i reklam z apteki „Pod Złotym Tygrysem”, Muzeum Farmacji UJ CM, IKS 1819.

${ }^{10}$ Ulotki produktów z serii Balnodor Jahra. Katalog opakowań i reklam. Muzeum Farmacji UJ CM, IKS 1819.

${ }^{11}$ A. Rzepiela, Hygieja w ikonografi farmaceutycznej na przykladzie zbiorów Muzeum Farmacji Uniwersytetu Jagiellońskiego, „Farmacja Polska” 2006, nr 24, s. 1087-1095. 
również na utrzymanych w stylu secesji, pamiątkowych tableaux i okolicznościowych dyplomach, których wiele znajduje się w ekspozycji krakowskiego Muzeum Farmacji. Jednym z nich jest dyplom, jaki wraz ze srebrnym medalem otrzymał na II Międzynarodowej Wystawie Lekarskiej w Pradze w 1896 roku za prezentowane wyroby krakowski aptekarz - mgr Jan Wiesław Radwański ${ }^{12}$ (il. VI). Tuż obok wisi dyplom wydany z okazji przyjęcia go w 1896 roku w poczet członków Austriackiego Towarzystwa Farmaceutycznego. To barwna litografia ozdobiona inicjałem D (tekst zaczyna się od słów Der allgemeine österreichische...) umieszczonym w otoczeniu secesyjnie stylizowanych liści i kwiatów. Pośrodku inicjału znajduje się wizerunek Higiei z czarą i wężem ${ }^{13}$. Identyczny dyplom, należący do mgr. Karola Symanowicza, pochodzi z roku 1913 i jest również eksponowany w muzeum ${ }^{14}$. Uwagę zwiedzających zwraca także, ozdobione secesyjnie udrapowaną wstążką, okolicznościowe, pochodzące z lat 1909-1915, tableaux członków - założonego w roku 1897 na Uniwersytecie w Dorpacie - Stowarzyszenia Studentów Polskich „Lechicja” ${ }^{15}$. Kolejnym eksponatem z tej grupy jest dyplom honorowy, jaki na odbywającym się w 1900 roku w Krakowie IX Zjeździe Lekarzy i Przyrodników został przyznany Galicyjskiemu Towarzystwu Farmaceutycznemu „Unitas” za wydawa-

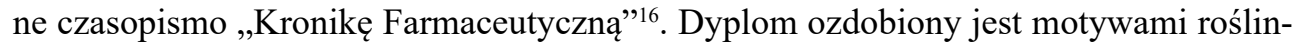
nymi, m.in. liśćmi dębu, a także podobizną Higiei, autorstwa znanego polskiego malarza Piotra Stachiewicza (1858-1938). Oryginalny wizerunek jest rysunkiem, wykonanym węglem, w formie medalionu o średnicy $47 \mathrm{~cm}$. Przedstawia on popiersie bogini trzymającej w rękach czarę, z której pije wąż okalający medalion w formie ramy. Rysunek ten również znajduje się w ekspozycji krakowskiego Muzeum Farmacji ${ }^{17}$.

W zbiorach krakowskiego muzeum wiele eksponatów, które pochodzą z przełomu XIX i XX wieku, posiada wyraźną stylizację charakterystyczną dla stylu secesji. Przykładem są znajdujące się w jednej z piwnic ekspozycji muzealnej „filtry do wody Berkefelda" z wkładem z ziemi okrzemkowej, datowane mniej więcej na rok 1900 (il. VII), szklane i ceramiczne naczynia apteczne oraz bogaty zbiór reklam, etykiet i opakowań na leki, pochodzący z różnych polskich i zagranicznych aptek. Wymienić tu można, przykładowo, opakowania z lwowskiej apteki „Pod Gwiazdą” Piotra Mikolascha, z apteki Gustawa Szancera w Przemyślu, z apteki „Pod Świętym Duchem” Antoniego Pilewskiego we Lwowie, z-(Cesarsko-Królewskiej Obwodowej i Salinarnej apteki Karola Szymanowicza w Bochni, z apteki Mariana Kawskiego w Sanoku, z apteki Jana Gessnera w Warszawie i z apteki „Pod Gwiazdą” Gustawa Adama w Stanisławowie ${ }^{18}$ (il. VIII-X).

Przeglądając wychodzące na przełomie XIX i XX wieku czasopisma aptekarskie, zauważamy, że około roku 1904 zmieniła się ich szata graficzna. Zarówno ukazująca się w Krakowie „Kronika Farmaceutyczna”, jak i wychodzące we Lwowie „Czasopismo Towarzystwa Aptekarskiego” otrzymały nowe zdobnictwo. Drukowane w czasopismach ogłoszenia i reklamy otoczone zostały charakterystyczną dla tego okresu falistą linią,

\footnotetext{
12 Katalog zbiorów Muzeum Farmacji, KGZ 1563, teka 55/2.

13 Katalog zbiorów Muzeum Farmacji, KGZ 1562, teka 55/1.

14 Katalog zbiorów Muzeum Farmacji, KGZ 1321, teka 35/3.

15 Katalog zbiorów Muzeum Farmacji, KGZ 3268.

16 Katalog zbiorów Muzeum Farmacji, KGZ 4646.

17 Katalog zbiorów Muzeum Farmacji, KGZ 4731.

18 Archiwum Muzeum Farmacji, teka 10.
} 
a w tekście znalazło się wiele charakterystycznych ozdobników o motywach zwierzęcych czy kwiatowych. Podobny wygląd przybrały reklamy aptek i ich wyrobów, jakie zamieszczano w krakowskich dziennikach i kalendarzach. Wiele z tych reklam można również zobaczyć w Muzeum Farmacji na wspomnianej już wystawie „Co zostało z dawnych krakowskich aptek".

\section{Bibliografia}

Archiwum Muzeum Farmacji, teka 10.

Bela Z., Style mebli aptecznych w stałej ekspozycji krakowskiego Muzeum Farmacji [w:] Rozwój aptekarstwa ślaskiego. Moda i styl w aptekach polskich ze szczególnym uwzględnieniem Ślaska i jego specyfiki, red. A. Marek, B. Urbanek, Katowice 2014, s. 261-280.

Katalog Fabriken Pharmaceutischer Bedarfsartikel Hammer \& Voršak, Wien 1901.

Katalog firmy Hermann Steinbuch vormals F.A. Wolf \& Söhne, Wien 1911, s. 9-19.

Katalog opakowań i reklam z apteki „Pod Złotym Tygrysem”, Muzeum Farmacji UJ CM, IKS 1819.

Katalog zbiorów Muzeum Farmacji, KGZ 1563, teka 55/2.

Katalog zbiorów Muzeum Farmacji, KGZ 1321, teka 35/3.

Katalog zbiorów Muzeum Farmacji, KGZ 1562, teka 55/1.

Katalog zbiorów Muzeum Farmacji, KGZ 3268.

Katalog zbiorów Muzeum Farmacji, KGZ 4646.

Katalog zbiorów Muzeum Farmacji, KGZ 4731.

Kowalska B., Od impresjonizmu do konceptualizmu. Odkrycia sztuki, Warszawa 1989.

Madsen S.-T., Art Nouveau, Warszawa 1987.

Pankiewicz T., Apteka w getcie krakowskim, Kraków 1947.

Roeske W., Polskie apteki, Wrocław-Warszawa-Kraków 1971.

Rzepiela A., Hygieja w ikonografii farmaceutycznej na przykładzie zbiorów Muzeum Farmacji Uniwersytetu Jagiellońskiego, „Farmacja Polska” 2006, nr 24, s. 1087-1095.

Ulotki produktów z serii Balnodor Jahra. Katalog opakowań i reklam. Muzeum Farmacji UJ CM, IKS 1819. 